\title{
Coeliac Disease Pathogenesis: The Uncertainties of a Well-Known Immune Mediated Disorder
}

\author{
Margaret R. Dunne ${ }^{1 \dagger}$, Greg Byrne ${ }^{2 \star t}$, Fernando G. Chirdo ${ }^{3}$ and Conleth Feighery ${ }^{4}$ \\ ${ }^{1}$ Department of Surgery, Trinity Translational Medicine Institute, Trinity College Dublin, St. James's Hospital, Dublin, Ireland, \\ ${ }^{2}$ School of Biological \& Health Sciences, Technological University, Dublin, Ireland, ${ }^{3}$ Instituto de Estudios Inmunologicos y \\ Fisiopatologicos - IIFP (UNLP-CONICET), National University of La Plata, La Plata, Argentina, ${ }^{4}$ Department of Immunology, \\ Trinity College Dublin and St. James's Hospital, Dublin, Ireland
}

OPEN ACCESS

Edited by:

Pinyi Lu,

Biotechnology HPC Software Applications Institute (BHSAl),

United States

Reviewed by:

Walburga Dieterich, University of Erlangen

Nuremberg, Germany

Heather Galipeau,

McMaster University, Canada

${ }^{*}$ Correspondence:

Greg Byrne

greg.byrne@tudublin.ie

tThese authors have contributed equally to this work

Specialty section:

This article was submitted to Nutritional Immunology,

a section of the journal

Frontiers in Immunology

Received: 21 November 2019 Accepted: 28 May 2020 Published: 08 July 2020

Citation:

Dunne MR, Byrne G, Chirdo FG and Feighery C (2020) Coeliac Disease Pathogenesis: The Uncertainties of a Well-Known Immune Mediated

Disorder. Front. Immunol. 11:1374. doi: 10.3389/fimmu.2020.01374
Coeliac disease is a common small bowel enteropathy arising in genetically predisposed individuals and caused by ingestion of gluten in the diet. Great advances have been made in understanding the role of the adaptive immune system in response to gluten peptides. Despite detailed knowledge of these adaptive immune mechanisms, the complete series of pathogenic events responsible for development of the tissue lesion remains less certain. This review contributes to the field by discussing additional mechanisms which may also contribute to pathogenesis. These include the production of cytokines such as interleukin-15 by intestinal epithelial cells and local antigen presenting cells as a pivotal event in the disease process. A subset of unconventional $T$ cells called gamma/delta $T$ cells are also persistently expanded in the coeliac disease (CD) small intestinal epithelium and recent analysis has shown that these cells contribute to pathogenic inflammation. Other unconventional $T$ cell subsets may play a local immunoregulatory role and require further study. It has also been suggested that, in addition to activation of pathogenic $T$ helper cells by gluten peptides, other peptides may directly interact with the intestinal mucosa, further contributing to the disease process. We also discuss how myofibroblasts, a major source of tissue transglutaminase and metalloproteases, may play a key role in intestinal tissue remodeling. Contribution of each of these factors to pathogenesis is discussed to enhance our view of this complex disorder and to contribute to a wider understanding of chronic immunemediated disease.

Keywords: coeliac disease, pathogenesis, enteropathy, immunopathology, innate and adaptive immune response, molecular mechanisms of disease

\section{INTRODUCTION}

Coeliac disease $(\mathrm{CD})$ is a common inflammatory disorder of the small intestine resulting in malabsorption. The seminal breakthrough was the discovery by Willem Dicke in 1950 that the wheat protein gluten was the essential trigger causing the disease (1). In the following decades, debate continued about the pathogenic mechanisms involved. Various theories were considered, including the concept that gluten caused direct toxic damage to the intestine, that an enzyme deficiency resulted in failure of gluten degradation or that gluten activated the immune system, driving consequential gut damage (2). 
Gluten-induced activation of the adaptive immune response has now been described in great detail and a central role for immune system involvement is widely accepted. A key finding supporting the role of the adaptive immune response was the discovery that certain MHC class II molecules, in particular HLA-DQ2, were a critical requirement for the development of $\mathrm{CD}(3,4)$. It was subsequently demonstrated that glutenderived peptides bound avidly to these MHC class II molecules, enabling $\mathrm{T}$ helper $\left(\mathrm{T}_{\mathrm{H}}\right)$ cell activation $(5,6)$. The binding of these peptides was markedly enhanced following their modification by the enzyme tissue transglutaminase (TG2) (7). The role of TG2 was in part a serendipitous discovery, following the finding that specific IgA antibodies found in CD were directed against this enzyme (8).

Although initially considered a homogenous disorder, it is now recognized that $\mathrm{CD}$ encompasses a wider clinical spectrum. Patients can report a range of symptoms, some with clear evidence of malabsorption and others virtually asymptomatic (9, 10). Following treatment with a gluten-free diet, some patients become acutely and rapidly sensitive to accidental gluten exposure, whereas others may show little evidence of a reaction (11-13). A pediatric presentation was the early classic form of CD but it is now accepted that the condition can present at any age, even into the seventh and eighth decades (14). A true increasing incidence of $\mathrm{CD}$ is also reported, presumably reflecting a range of yet to be identified environmental triggers of the condition (15). The histological lesion can also vary considerably, with some patients having only a minimal lymphocyte infiltration of the gut epithelium (16), while others display profound changes, so called villous atrophy $(17,18)$. The term "potential coeliac disease" is also used for people with normal small intestinal mucosa who are at increased risk of developing CD as indicated by positive coeliac serology (10). Malignancy is the final outcome in a subset of patients, but fortunately develops only in a minority of subjects (9). The common type of malignancy associated with $\mathrm{CD}$, enteropathy-associated $\mathrm{T}$ cell lymphoma (EATL), is lymphocytic in origin, reflecting the profound dysregulating effects gluten has on the local immune system.

$\mathrm{CD}$ is sometimes considered to be an auto-immune disorder and certain features support this contention, including a female predisposition, HLA association, and comorbidity with many classic autoimmune diseases, in particular thyroid disease (e.g., Grave's disease, Hashimoto's thyroiditis) and insulin dependent diabetes mellitus (19). As in other auto-immune conditions, a contribution by the intestinal microbiome is postulated (20). However, if CD is caused by autoimmunity, one feature makes this pathology unique: exclusion of an exogenous trigger i.e., gluten from the diet, causes remission of symptoms and mucosal damage. Nonetheless, some doubt continues as to whether gluten exclusion fully restores a normal small intestinal mucosa or whether consequences of the previous strong immune activation remain. It has long been observed that chronic immune activation by gluten in CD patients induces a permanent change in the intra-epithelial lymphocyte (IEL) compartment, characterized by an expanded and persistent presence of $\gamma / \delta$ IELs, which was recently verified using cell sequencing methodology (21-23). This observation suggests that even in apparently healthy tissue, some subtle changes persist. However, such findings are difficult to interpret given that many patients ostensibly on a gluten-free diet continue to consume trace amounts of gluten (24).

Irrespective of the above variables, a constant feature in all patients is the MHC class II association, with virtually all displaying a HLA-DQ2 or HLA-DQ8 genotype (25). As many as 39 other non-HLA loci have been found to associate with CD and their potential contribution to disease heterogeneity has yet to be determined. Remarkably, many non-coding regions are located in these loci and their potential regulatory effects have just started to be revealed (26). In addition, epigenetic factors may modulate disease risk (27).

In addition to the well-established evidence of the adaptive immune response to gluten, leading to damage to the intestine, in this review we consider the possible involvement of other immune components. Of note, it has been reported that activation of the innate immune response may be a prerequisite for gluten stimulation of the adaptive response (28$30)$. The $\alpha$-gliadin peptide, p31-43, claimed to be responsible for activation of this innate response, was also reported to cause direct damage to the CD mucosa (28). Many studies report that innate immune components such as neutrophils (31), eosinophils $(32-34)$, mast cells $(35,36)$ and complement proteins $(37)$ are activated in the disease process and potentially contribute to disease pathogenesis. Consideration of this information may lead to a more comprehensive understanding of CD pathology.

\section{HOW DOES THE LESION DEVELOP IN CD?}

Despite the series of seminal discoveries made concerning activation of the adaptive immune system in $\mathrm{CD}$, the precise mechanisms responsible for development of the lesion remain uncertain. Specifically, what events cause the tall small intestinal villi to take on a flattened appearance in which villi are either entirely absent or stubby in appearance? It is evident from both in vivo and in vitro studies that enterocyte damage happens rapidly following gluten exposure (38-43). Yet the question remains, how does this lead to the eventual pathological features of the lesion? Interestingly, although enterocytes are targeted in CD, there is no evidence of tissue necrosis or ulceration, as is observed in small intestinal Crohn's disease (44). Although it is evident that lymphocytes closely located to enterocytes display cytotoxic properties $(45,46)$, is lymphocyte cytotoxicity the exclusive or principal mechanism responsible for the tissue lesion in $\mathrm{CD}$ ?

\section{THE HISTOLOGICAL LESION IN CD}

Biopsy of the small intestine is still the gold standard diagnostic test in the investigation of $\mathrm{CD}$. The lesion can display a range of abnormalities and Marsh proposed a grading system, subsequently modified by Oberhuber et al. (18), which is now commonly used. The Marsh I lesion is characterized by an almost normal mucosa except for the infiltration of villi by IELs, the Marsh II lesion by the additional presence of crypt hypertrophy, and the Marsh III lesion by flattening of the mucosa caused 
by so-called villous atrophy and swelling of the lamina propria. Although an increase in IELs is observed in all CD biopsies, in some patients this increase may be limited to the tip of villi $(16,47)$; even in the presence of this minimal lesion, some display typical clinical features of CD including malabsorption. Paradoxically, in other patients with a Marsh I lesion, there may be no apparent evidence of malabsorption: these include patients with dermatitis herpetiformis (48), first degree relatives of CD patients and individuals with potential CD (10).

Although villous atrophy and infiltration of IELs are the major reported features in coeliac mucosa, this is based on the limited information provided by standard tissue staining and the twodimensional image observed with the light microscope. More details can be provided by additional staining of further cell populations and other structures. One feature of the remodeled mucosa is alteration in the microvasculature and these immature vascular structures may result in increased vessel permeability, allowing cells and molecules access to the tissue (49). It has been proposed that improved understanding of the true nature of the CD lesion could be deduced by 3-D printing and computerized modeling of the tissue (50). In recent times, robust flow cytometry methodology and quantification of gamma/delta $(\gamma \delta) \mathrm{T}$ cells have been proposed as complementary methods for aiding CD diagnosis and monitoring, particularly helpful in resolution of more difficult clinical cases $(51,52)$. Analysis of an increase in $\gamma \delta^{+} \mathrm{T}$ cells with a decrease in CD3- IEL, the so-called "coeliac lymphogram," was also shown to be useful in diagnosing seronegative CD cases (53). Such novel methods have proven superior to traditional serological monitoring methods.

\section{THE ENTEROCYTE-A TARGET CELL IN CD?}

Abnormalities in the morphology of enterocytes are usually present in CD but are rarely commented on in routine histology reports. These changes include a reduction in cell height with the cell assuming a cuboidal instead of the normal columnar shape and the migration of the nucleus from the typically basal to a more apical position (54). Using a high content Cellomics analysis system, we studied enterocyte morphology in detail and confirmed a reduction in enterocyte height and noted shape changes in the nucleus (55). Importantly, these changes were found not only in patients with active $\mathrm{CD}$ but also in patients with potential CD. Changes in the microvilli at the enterocyte apex may also be noted, even when examined by light microscopy, although these features are more clearly evident when studied by electron microscopy (56). Microvilli are found to be either sparse, absent or have irregular shapes.

These abnormal enterocyte features are presumably caused by the inflammatory response in CD. The changes may preface cell death, and indeed, increased small intestinal enterocyte apoptosis has been demonstrated in CD in several studies $(40,57,58)$. Using TUNEL staining to detect fragmented DNA, Moss et al. reported this finding in patients with untreated $\mathrm{CD}$, and evidence of apoptosis correlated with the level of enterocyte proliferation (57). Maiuri et al. also described increased apoptosis in CD tissue but these abnormalities appeared confined to tissue areas displaying evidence of damage (40). Another study reported increased expression of both FAS and FAS ligand death receptors in the duodenal epithelium in untreated CD patients, together with increased perforin expression and number of TUNEL positive cells (59).

Raised circulating levels of intestinal fatty acid-binding protein (I-FABP) in patients with active CD also provides evidence of enterocyte damage (60-62). I-FABP is a low molecular weight protein, specific to small intestinal epithelial cells. Since I-FABP is highly expressed in the cytoplasm of these cells, the circulating level of I-FABP is a very sensitive marker for monitoring enterocyte damage and has been proposed as a potential biomarker of disease activity in CD (63). Interestingly, in patients with severe enteropathy, strong expression of IFABP is also noted in the crypts, and this may be linked to an accelerated developmental program of enterocyte proliferation and differentiation. As a consequence, while I-FABP is expressed in fully differentiated enterocytes in homeostasis, it appears earlier in crypt enterocytes when enteropathy is present (64).

\section{A BROADER ROLE FOR INTESTINAL EPITHELIAL CELLS?}

Enterocytes are the predominant intestinal epithelial cell type and together with other cells, including goblet cells, Paneth cells and $\mathrm{M}$ cells, act as a first line of defense against potential access from the gut of microorganisms and other noxious agents $(65,66)$. However, intestinal epithelial cells have a wider role in gut homeostasis, interacting on a constant basis with commensal organisms and influencing the behavior of cells of both the innate and adaptive immune system. Reactions with microogranisms and danger signals is facilitated by the epithelial surface expression of a range of innate receptors including toll like receptors (67). Epithelial cells influence the behavior of many intestinal cell populations including innate lymphoid cells (ILC), neutrophils, basophils, macrophages, T cells and B cells through the production and release of a range of cytokines and chemokines including tumor necrosis factor alpha (TNF)$\alpha$, interleukin (IL)-8, IL-18, IL-25, transforming growth factor (TGF)- $\beta$ and B cell activating factor $(66,68)$. Amongst its many roles, a key function of intestinal epithelial cells is to allow the orderly paracellular absorption of nutrients and ions and to prevent access to potentially damaging substances including dietary antigens. This led to the study of a series of tight junction structures and the discovery of the protein zonulin, the only known physiological modulator of intercellular tight junctions (69). Increased release of zonulin is associated with gut barrier dysfunction and gliadin peptides have been reported to trigger this reaction (65).

\section{A ROLE FOR DIRECT GLUTEN-INDUCED ENTEROCYTE DAMAGE?}

Details of enterocyte pathology following gluten exposure have been investigated by both in vitro and in vivo challenge 


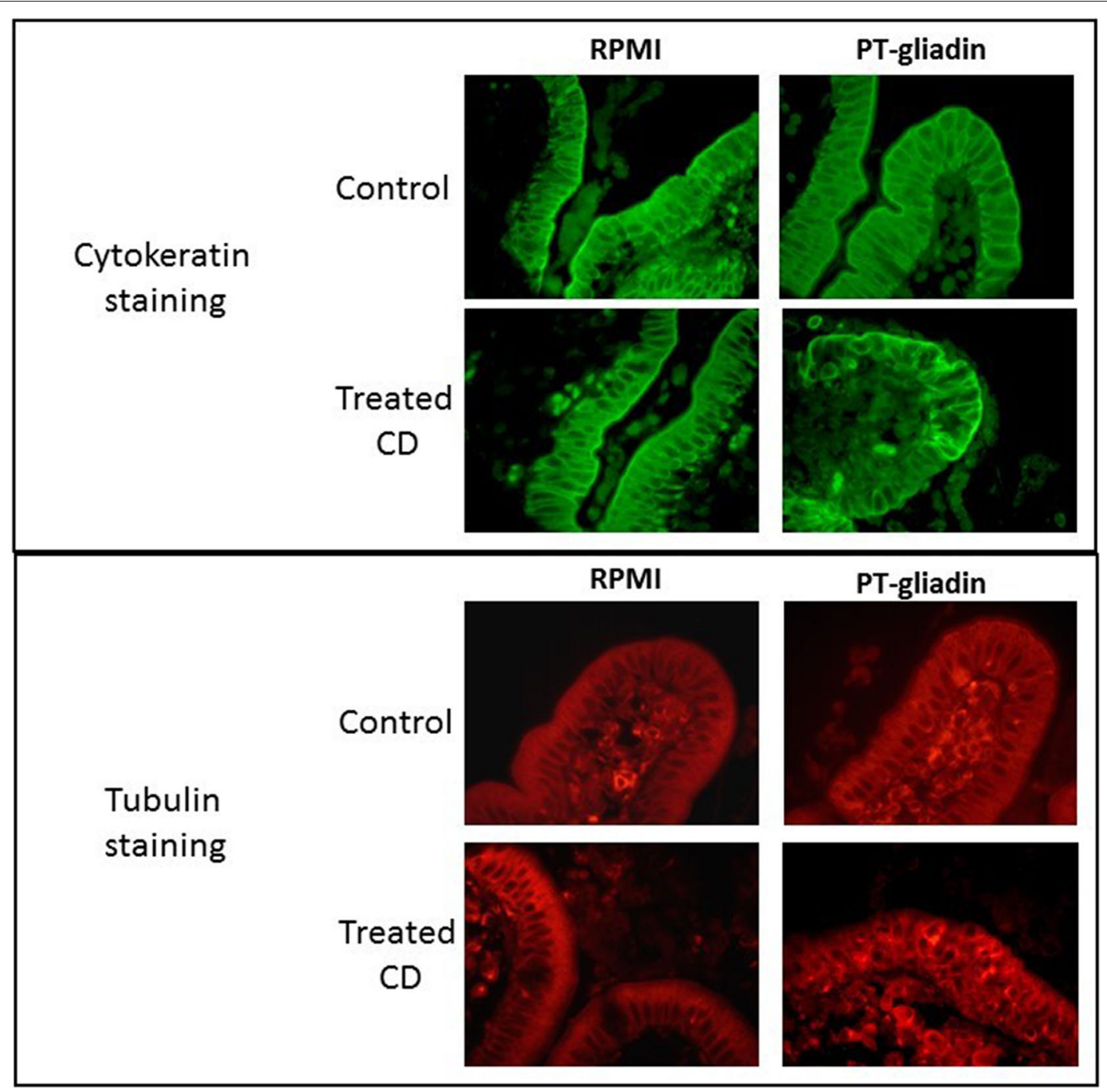

FIGURE 1 | Direct effect of peptic-tryptic digests of gliadin on intestinal enterocytes. Representative images of organ culture of healthy $(n=5)$ and coeliac $(n=5)$ biopsies in the presence or absence of peptic-tryptic (PT) digests of gliadin demonstrates direct effects of gliadin. Treatment of coeliac biopsies for $24 \mathrm{~h}$ with PT gliadin reveals significant changes in cytokeratin and tubulin staining, as demonstrated by fluorescence microscopy.

studies. In organ culture of biopsies taken from coeliac patients co-cultured with gluten derived proteins, evidence of rapid changes in enterocyte morphology has been reported. In several studies, gluten caused reduction in enterocyte height (70-73) and increased apoptosis of enterocytes $(28,41,74,75)$. We also performed organ culture experiments employing a peptic/tryptic digest of gluten and demonstrated derangement of several enterocyte cytoskeletal proteins, including microfilaments, intermediate filaments and microtubules; these changes were evident after $4 \mathrm{~h}$ of culture but were even more marked after $24 \mathrm{~h}$ (Figure 1) (76).

Several short-term in vivo challenge studies also reported evidence of rapid enterocyte damage following infusion of gluten fractions into the small intestine. When small intestinal biopsies were taken at hourly intervals, significant histological damage was observed after patients were given either gluten (77), gliadin subfractions $(38,39)$ or the associated wheat protein glutenin (78). The abnormalities included a reduction in enterocyte height, an increase in IELs and a reduction in the villous/crypt ratio. In some instances, these changes were noted as early as $2 \mathrm{~h}$ after gluten exposure (78).

Taken together, these studies demonstrate rapid changes in coeliac enterocyte morphology following gluten exposure. The mechanisms responsible have yet to be identified. Although a rapid response is more typical of innate immune involvement, there is now evidence that a histological and cytokine response to gluten and immunodominant gliadin peptides can take place within hours. A study by Fraser et al. demonstrated that in vivo challenge with residues 56-75 of $\alpha$-gliadin resulted in reduction of enterocyte height and an increase in IELs in biopsy tissue within just $4 \mathrm{~h}$ (79). Moreover, it has been recently reported that oral gluten challenge causes a significant elevation of plasma IL-2, 
suggestive of rapid activation of $\mathrm{T}$ lymphocytes, again within $4 \mathrm{~h}$ (80). The findings of these studies support a prominent role for adaptive immunity in causing early tissue changes in the CD lesion.

\section{A ROLE FOR ENTEROCYTE PROLIFERATION?}

It has been suggested that hyperproliferation of enterocytes is the principal pathological event responsible for apparent villous atrophy in $\mathrm{CD}$ mucosa, rather than direct destruction of the villous structure $(50,81,82)$. Marsh and Heal in particular have argued this point and state that the term "villous atrophy" is a misnomer (50). They postulate that the overgrowth of the crypt cell population surrounds and dwarfs the villous structure and cause its shrunken appearance. Crypt cell proliferation was investigated by Wright et al. and an up to 6-fold increase in crypt cell production was calculated with an associated increase in the mitotic index (83).

The increased crypt cell proliferation may due to the reparative process to replace damaged enterocytes shed into the intestinal lumen. However, it has also been reported that proliferation may be due to a direct effect of gliadin peptides on the coeliac mucosa (84). In cultured coeliac duodenal biopsy tissue the p31-43 gliadin peptide was shown to increase crypt cell proliferation, apparently via the epidermal growth factor pathway (85). This effect was mediated by enhancing epithelial growth factor receptor signaling in a mechanism involving altered vesicular trafficking $(84,86)$. It was also postulated that this proliferative effect was further augmented by increased IL-15 production, stimulated by the gliadin peptide (29).

\section{A ROLE FOR GLIADIN PEPTIDES IN CAUSING AN INNATE RESPONSE?}

In addition to its reported effect on crypt cell proliferation (84), many additional studies have focused on the $\alpha$-gliadin peptide, p31-43 and its potential to cause direct activation of the innate immune system. Within $20 \mathrm{~min}$ of exposure to this peptide evidence of enterocyte actin reorganization was reported in organ culture experiments (87). Further study has revealed various additional pathogenic effects. p31-43 was shown to inhibit the subunit of the chloride channel (CFTR) and thereby cause NF-kB activation, induction of IL-15 and TG2 activation, with a range of inflammatory consequences (88). Moreover, p31-43 is able to self-assemble in oligomers with potential important effects (89). In vivo analysis in a murine model showed that activation of the NLRP3 inflammasome, either by direct detection of oligomers or indirectly by sensing danger signals, is required for histological changes in the small intestinal mucosa (90). Finally, the peptide was shown to induce a type I interferon (IFN) response in mice (91). Of note, high levels of IFN $\alpha$ can be observed in the duodenal mucosa from coeliac patients (84) and this cytokine has been suggested to promote $\mathrm{T}$ helper $\left(\mathrm{T}_{\mathrm{H}}\right)$ type 1 responses in $\mathrm{CD}(92)$.
More recently, various studies were conducted to evaluate the role of a particular enteric virus which causes the induction of proinflammatory signals that may promote breakdown of oral tolerance to gluten (93). Commensal microbiota also has a role to play in the induction of local inflammation. Elastase-producing Pseudomonas aeruginosa isolated from the duodenal biopsies of CD patients was able to degrade a gluten-derived 33-mer peptide, producing shorter fragments which cross the mucosal barrier and display increased immunogenicity (94). Therefore, viral infection and the activity of $P$. aeruginosa, as examples of members of the microbiota which can elicit proinflammatory signals on intestinal cells which drive or amplify villous damage. Other mechanisms, apart from conventional immunogenic peptides, that may play a role are the amylase trypsin inhibitors present in wheat. These proteins are resistant to intestinal digestion, can directly activate Toll-like receptor 4 (TLR4) and may support intestinal $\mathrm{T}$ cell activation in celiac disease (95). However, the main immunogenic peptide, responsible for stimulating the adaptive immune response is a 33-mer gliadin peptide, p56-88, which contains several overlapping sequences that bind with high affinity to susceptibility HLA molecules (92). A further small eight residue gliadin peptide is reported to act through the stimulation of particular dendritic cells, can amplify the inflammatory response (96).

\section{A ROLE FOR CONVENTIONAL AND UNCONVENTIONAL LYMPHOCYTES?}

T lymphocytes and B cell derived plasma cells are markedly increased in the coeliac lesion. In the untreated coeliac mucosa, plasma cells secreting IgA are increased 2.4-fold and represent some $66 \%$ of antibody secreting cells (97). Increases in IgM and IgG secreting cells also are found, with these cells accounting for some 28 and $6 \%$ of plasma cells in the lesion. Antibodies of all three isotypes to gliadin and auto-antigen targets can be detected not only in intestinal secretions but also in the circulation. Assays for these antibodies are of immense value in the diagnosis and monitoring of disease activity in $\mathrm{CD}$ patients. In addition, gutresident plasma cells presenting the immunodominant gluten peptide DQ2.5-glia- $\alpha$ la have been shown to be abundant in the $\mathrm{CD}$ lesion, suggesting an important local antigen presentation role (98). These cells also act as a source of cytokines, including the chemokine CXCL10 (99).

Gluten-reactive $\mathrm{T}$ lymphocytes are found in the lamina propria and are comprised of $\alpha / \beta$ T cell receptor positive cells bearing a CD4 co-receptor, identifying them as $\mathrm{T}_{\mathrm{H}}$ cells $(3,100)$. However, cloning studies have revealed that only $0.5-1.8 \%$ of CD gut-derived CD4 T cells are truly gluten reactive (101). These gluten-reactive cells display a $\mathrm{T}_{\mathrm{H}} 1$ phenotype in response to gluten peptides, with cytokine production predominated by IFN $\gamma$ (102). Gliadin-specific $\mathrm{T}_{\mathrm{H}} 17$ cells have also been described, which co-produce IL-17 and IFN $\gamma$ (103). Gluten reactive $\mathrm{CD}^{+} \mathrm{T}$ cells have also been described in the lamina propria following challenge with the pA2 gliadin peptide (41). Nonetheless, studies in mice and humans have shown that the presence of these gluten-reactive $\mathrm{T}$ cells alone is not sufficient 
to drive pathological changes to the villous architecture (104106). Thus, in potential $\mathrm{CD}$, where individuals demonstrate an adaptive immune response to gluten, characterized by the presence of serum endomysial antibodies, no histological lesion is present. This suggests that additional factors may be required to drive tissue damage (107).

Parallels have been drawn between the progression of $\mathrm{CD}$ and graft vs. host disease, suggesting a key role for $\mathrm{T}$ cells in disease pathogenesis (108). In addition to glutenreactive $\mathrm{CD}^{+} \alpha / \beta \mathrm{T}$ cells, a role for $\mathrm{CD}^{+} \alpha / \beta$ IELs in enterocyte destruction has also been shown, whereby these cells acquire an aberrant natural killer (NK)-like phenotype and kill enterocytes in a $\mathrm{T}$ cell receptor (TCR)-independent manner. These mechanisms, driven by IL-15 $(46,68)$, are summarized in Figure 2. This NK-like action is characterized by strong IFN $\gamma$ production, upregulation of activating NK receptors NKG2D and CD94/NKG2C (46), concurrent downregulation of inhibitory coreceptors CD94/NKG2A (106) and cytotoxic ability. Engagement of activating NK receptors by stress molecules expressed on enterocytes triggers the cytolytic function of these $\mathrm{CD} 8^{+}$IELs. In patients with $\mathrm{CD}$, enterocytes upregulate expression of stress molecules such as heat shock proteins (HSP), MHC class I polypeptide-related sequence A (MICA), HLA-E and IL-15 (45, $109,110)$. However, gluten-reactive $\mathrm{CD} 4^{+} \mathrm{T}$ cells have been shown to be required to fully license the cytolytic NK activity of these $\mathrm{CD}^{+}$IELs $(106,111,112)$. A recent mouse model of $\mathrm{CD}$ has also demonstrated the key role of $\mathrm{CD} 4^{+} \mathrm{T}$ cells and HLA-DQ8 in mediating cytotoxic lymphocyte (CTL)-driven villous destruction (111). Depletion of either $\mathrm{CD}^{+}$or $\mathrm{CD}^{+}$ $\mathrm{T}$ cell populations prevented villous damage in these transgenic HLA-DQ8 ${ }^{+}$mice overexpressing IL-15. $\mathrm{CD}^{+}{ }^{+} \mathrm{T}$ cell depletion resulted in a failure of $\mathrm{CD} 8^{+}$CTLs to upregulate RAE-1, the murine ligand for NKG2D, providing further evidence that the NKG2D pathway is important in CD4-mediated CTL licensing. Upregulation of QA-1, the mouse ligand for NKG2 receptors paired with CD94, was unaffected by CD4 depletion, showing that this mechanism is specific to NKG2D. This study also revealed critical roles for gluten, IL-15, HLA-DQ8, TG2, and $\mathrm{CD} 4 \mathrm{~T}$ cells, working in concert to promote IFN $\gamma$ responses and expansion of activated cytolytic CD8 IELs which mediate villous atrophy. IFN $\gamma$, a prominent cytokine in $\mathrm{CD}$ pathogenesis, is produced not only by gluten-reactive lamina propria $\mathrm{T}_{\mathrm{H}}$ cells but also by populations of IELs, including $\gamma / \delta$ IELs (113). In addition to IL-15, cytokines IL-2 and IL-21 are two further important cytokine products of gluten reactive $\mathrm{T}_{\mathrm{H}}$ cells and contribute to the adaptive immune pathogenesis of $\mathrm{CD}(80,114-$ 116), however, of interest they were not shown to be critical for development of villous damage in this recent mouse model (107). A study on human tissue reports that the majority of $\mathrm{CD}$ patients overexpress both IL-15 and IL-21 and in vitro analysis showed these cytokines synergise to activate CTL IEL populations and thus drive villous damage, in a cooperative and non-redundant manner (117).

Intriguingly, individuals with potential $\mathrm{CD}$ do not demonstrate an increase in activating NK receptors nor IL-15 or IL-21, suggesting that additional factors may also be required to drive the full NK-like phenotype. Potential candidates include gut microbial components (118) or viral infection $(119,120)$. This is further supported by a recent study in which ubiquitous bacterial peptides were shown to activate gliadin reactive $\mathrm{T}$ cells, suggesting the possibility that common bacterial antigens could act as trigger stimuli in the development of CD (121).

Whereas, $\mathrm{CD} 4^{+} \mathrm{T}$ cells predominate in the lamina propria, the human small intestinal epithelium is predominantly populated by $\mathrm{CD}^{+} \alpha / \beta$ IELs, $\gamma / \delta$ IELs, and a smaller proportion of lymphocytes which do not express a $\mathrm{T}$ cell receptor, and therefore are classed as innate lymphocytes $(21,122)$. This latter population includes NK cells and ILCs. The $\mathrm{CD}^{+} \alpha / \beta$ IELs group also includes mucosal-associated invariant $\mathrm{T}$ (MAIT) cells and, albeit at low levels, invariant NK T (iNKT) cells (23). It is assumed that most of these cell types play a lesser but similar destructive role to their conventional $\mathrm{T}$ cell counterparts, since unconventional $\mathrm{T}$ cells constitutively express NK markers, display an effector memory phenotype, and are capable of rapid and potent cytolytic responses. Indeed, ILCs have been shown to be capable of killing enterocytes via the NK receptor DNAM1 (123).

The role of discrete IEL subsets warrants further study, particularly in light of the long-held observation that $\gamma / \delta$ IELs remain elevated in the coeliac gut long after removal of gluten from the diet and resolution of intestinal damage $(23,124)$. In contrast to the deleterious role proposed for $\mathrm{CD}^{+} \alpha / \beta$ IELs in $\mathrm{CD}$, it is hypothesized that $\gamma / \delta$ IELs play a more regulatory role in the gut $(125,126)$. We and others have described an abundance of $V \delta 1$ type $\gamma / \delta \mathrm{T}$ cells in the CD epithelium, in both pediatric and adult $\mathrm{CD}(23,127-130)$. This subset is known to possess potent cytolytic and regulatory functions in humans (131). Like their mouse counterparts, human $\gamma / \delta$ IELs in skin can secrete growth factors, specifically insulin-like growth factor, and play an important role in tissue repair (132). Whether this active role in tissue repair also occurs in the gut is unclear, but human $\mathrm{NKG}_{2} \mathrm{~A}^{+} \mathrm{CD} 8^{+} \gamma / \delta$ IELs have been shown to effectively dampen the proinflammatory and cytotoxic action of their $\alpha / \beta$ IELs counterparts via production of the immunosuppressive cytokine TGF- $\beta$ (133). TGF- $\beta$ is an immunosuppressive cytokine which exerts many anti-inflammatory effects, including driving differentiation of regulatory $\mathrm{T}$ cells and $\mathrm{T}_{\mathrm{H}} 17$ cell populations, which then produce more TGF- $\beta$ in an autocrine manner (134).

This suggests that lymphocyte-mediated damage to the coeliac small intestine may require dysregulation of both $\alpha / \beta$ and $\gamma / \delta$ IEL subtypes. In this scenario, a two-step process would be required to mediate gut damage $-\mathrm{CD} 8^{+} \alpha / \beta$ IELs acquire an aberrant NKlike cytotoxic phenotype coupled with $\gamma / \delta$ IELs losing regulatory function. This raises an intriguing possibility that maintenance of $\gamma / \delta \mathrm{T}$ cell regulatory function could explain the phenotype of potential CD, a scenario where $\gamma / \delta$ IELs keep $\alpha / \beta$ IEL cytotoxicity in check. Indeed, recent studies detailing long-term genomic and functional changes in the composition of the $\gamma / \delta$ IEL compartment in $\mathrm{CD}$ has shown that a subset of $\mathrm{V} \gamma 4^{+} / \mathrm{V} \delta 1^{+}$type $\gamma / \delta$ IELs, which have a role in tissue healing and homeostasis, is lost and replaced by a persistent IFN $\gamma$ producing $\mathrm{V} \delta 1^{+} \mathrm{T}$ cell population, thereby supporting this hypothesis $(21,22)$. The role of other lymphocyte subsets such as MAIT cells, iNKT cells and NK cells in CD is less well-understood (23). NK cells in particular appear to be capable of both deleterious and protective 
A भक

28

भक

Gluten

?

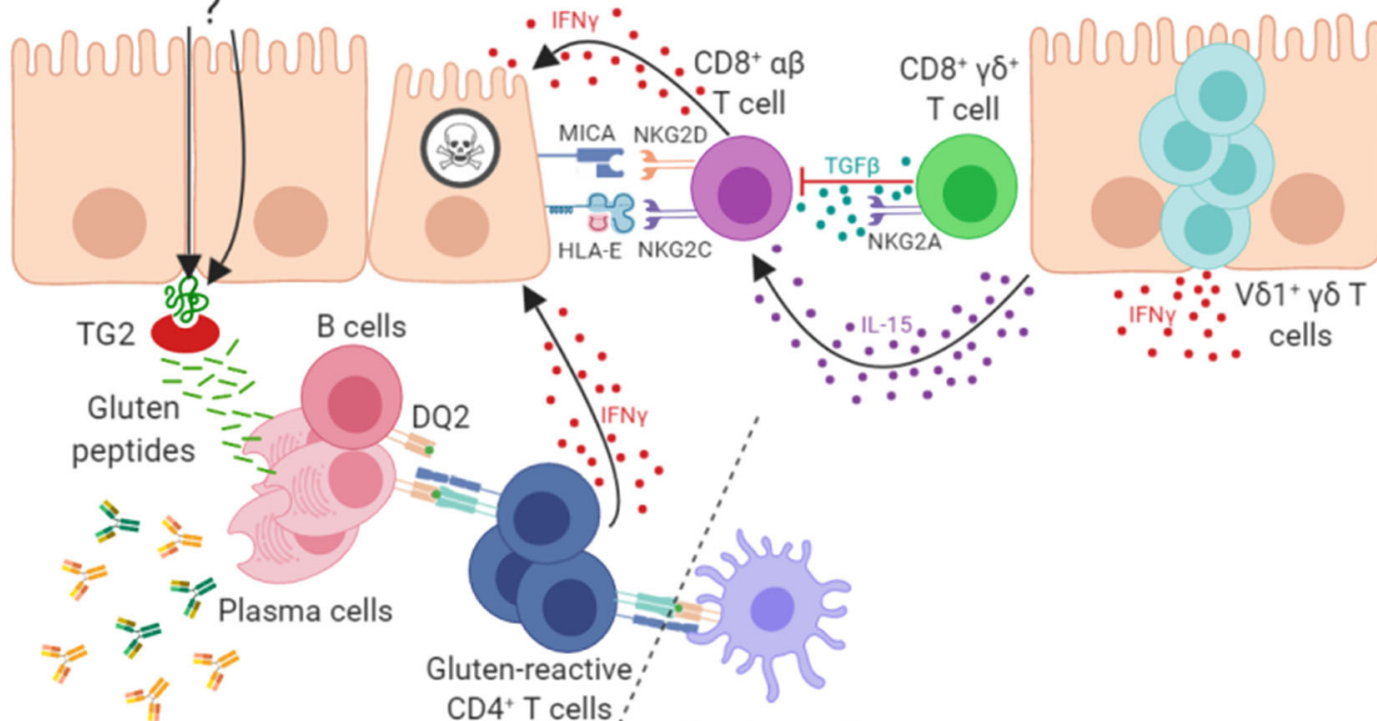

$\mathrm{CD}^{+} \mathrm{T}$ cells :

i Dendritic cell

MLN

B

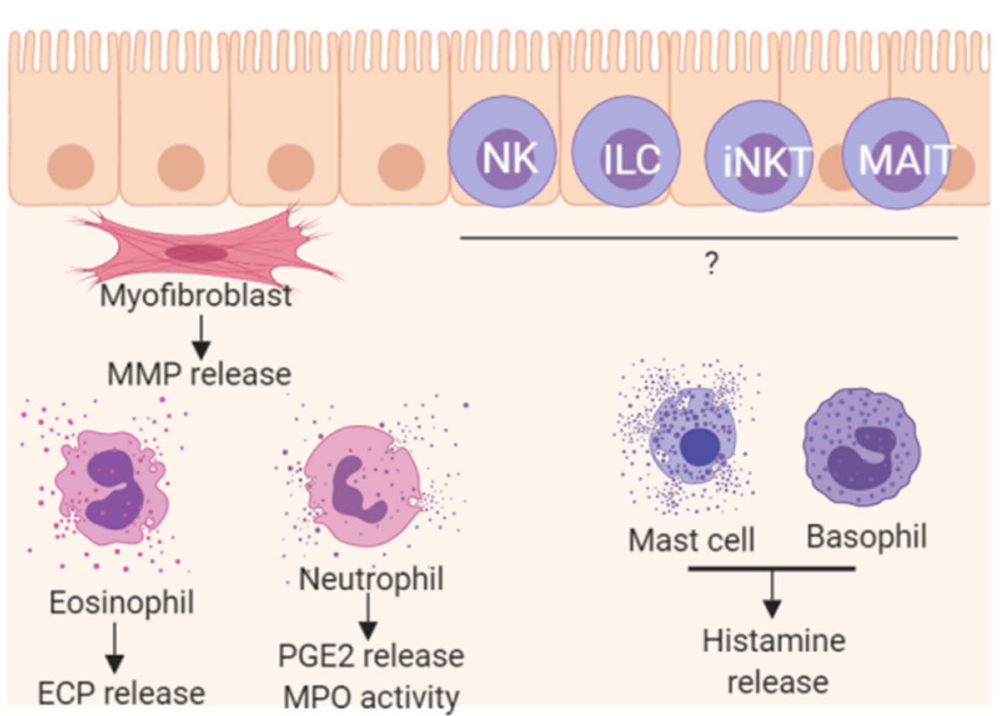

FIGURE 2 | Mechanisms of pathogenesis in coeliac disease. (A) It is well established that peptides derived from gluten are modified by TG2 and presented by antigen presenting cells in mesenteric lymph nodes (MLN) to CD4 ${ }^{+} T$ cells in the context of HLA-DQ2. The resulting $T_{H} 1$ type response results in IFN $\gamma$ production and intestinal inflammation. Chronic inflammation leads to expansion and persistence of $\mathrm{V} \delta 1^{+} \gamma \delta \mathrm{T}$ cells, which also contribute to IFN $\gamma$ production. Gluten peptides induce expression of IL-15 and stress molecules on enterocytes. The increased levels of IL-15 promote a NK-like phenotype in CD8 ${ }^{+} \mathrm{T}$ cells, contributing directly to enterocyte death. A proportion of $\mathrm{CD} 8^{+} \gamma \delta^{+} \mathrm{T}$ cells are thought to play a regulatory role through secretion of TGF- $\beta$. Plasma cells are also abundant in the lesion where many express the immunodominant gluten peptide DQ2.5-glia- $\alpha 1$ a and are induced to secrete antibodies that bind to TG2 and other targets. (B) Other less well-characterized mechanisms may play a role in lesion development. Intestinal myofibroblasts contribute to tissue remodeling by the secretion of matrix metalloproteases (MMPs) and via their contractile properties. These cells strongly express TG2 and $\alpha$-actin. Innate-like lymphocytes including natural killer (NK cells), innate lymphoid cells (ILC), invariant natural killer T cells (iNKT) and mucosal-associated invariant T (MAIT) cells may all contribute to the lesion. Granulocytes, including eosinophils, neutrophils and basophils, and also mast cells have been detected in higher levels and may be involved in disease pathogenesis. 
effects on the intestine and are also susceptible to functional and metabolic inhibition by TGF- $\beta$ (135); thus, their contribution to CD pathogenesis requires further elucidation (136).

\section{A ROLE FOR INNATE IMMUNE CELLS IN THE INTESTINAL LESION?}

In addition to the increased number of $\mathrm{T}$ cells and plasma cells in patients with active $\mathrm{CD}$, several studies describe increased populations of cells of the innate immune response, including eosinophils (32-34), basophils (50), mast cells (32, 35, 36), neutrophils $(137,138)$ and dendritic cells $(139,140)$. The potential contribution of both eosinophils and mast cells is supported by experiments involving gliadin challenge to an isolated segment of jejunum: this caused a four-fold increase in eosinophil granule specific protein secretion and a two-fold increase of histamine secretion, with maximum levels found within $1 \mathrm{~h}$ (141). A prominent extracellular deposit of eosinophil granule specific protein in the lamina propria of the atrophic intestinal mucosa was also found (31). Furthermore, eosinophils were noted to be in an activated state in $\mathrm{CD}$ and Brandtzaeg postulated that IgA might play a role in both eosinophil recruitment and activation (97). Mast cell numbers are also increased in active $\mathrm{CD}$, and found to correlate with the Marsh histological score and become cellular sources of TNF $\alpha$, IL-6, IL17 and monocyte chemoattractant protein $1(36,50)$. These data indicate that eosinophils and mast cells may both be involved in early gliadin-induced reactions in the small intestine and could contribute to the celiac lesion.

Neutrophils may also play a role in the coeliac lesion; in the early phase of gluten challenge, increased numbers of these cells have been observed with a 20 -fold increase calculated (137, 138). The rapid production of the chemokine IL- 8 by gluten activated $\mathrm{T}$ cells helps explain this neutrophil migration (80). In isolated jejunal segment experiments, gluten exposure caused a 5-fold increase in prostaglandin E2 (142) and a 3.5-fold increase in myeloperoxidase in the perfusion fluid (31). Furthermore, using gene expression profiling, chronic recruitment of activated neutrophils to CD biopsy tissue was discovered, even in patients in remission (143). In another study, after a 3-day gluten challenge, an increase in density of neutrophils as well as a rapid accumulation of monocyte/dendritic cells was observed (140). Of interest, in a murine study, gliadin peptides were found to have neutrophil chemoattractant properties (144). Dendritic cells are the critical players in innate immunity as well as adaptive response. Distinct subsets may display different functions, as induction of strong inflammatory response, driving the glutenspecific $\mathrm{T}$ cell response and control the immune response by inducing regulatory $\mathrm{T}$ cells $(139,145)$.

\section{A ROLE FOR ANTI-TG2 ANTIBODIES IN CD PATHOGENESIS?}

Detection of anti-TG2 autoantibodies is an exceptionally specific and sensitive tool used for CD diagnosis. The most commonly accepted model for the development of this autoantibody response is the hapten-carrier complex mechanism, as proposed by Sollid et al. (146). The hypothesis suggests that TG2-gliadin complexes are presented by TG2-specific B cells to gliadinspecific $\mathrm{T}$ cells and receive help for antibody production. While this model does not necessitate TG2-reactive T cells, separate studies by Comerford et al. and Ciccocioppo et al. demonstrate that these autoreactive $\mathrm{T}$ cells can be detected in patients $(147,148)$.

Whether or not autoantibodies play a role in the development of the lesion remains unclear. The fact that IgA deficiency does not preclude the development of $\mathrm{CD}$ suggests that IgA isotype autoantibodies are not essential for disease development. However, in the related gluten-sensitive condition dermatitis herpetiformis, it appears that autoantibodies against transglutaminase 3 (another member of the TG family) do appear to play a role in pathogenesis as demonstrated by the presence of IgA deposits at sites of neutrophil infiltration in the skin (149). Unlike CD, dermatitis herpetiformis is not observed in patients that are IgA deficient (150). It has been proposed that anti-TG2 autoantibodies influence the disease process in $\mathrm{CD}$ by having a direct effect upon enterocytes. Purified anti-TG2 antibodies have been shown to inhibit crypt cell differentiation (151), interfere with proliferation by binding membrane TG2 (85), and enhance gliadin trafficking across the gut epithelium (152). It has also been suggested that anti-TG2 could interfere with enterocyte differentiation by blocking TGF- $\beta$ activation, a cytokine that plays an important role in this process (151). Other effects have been reported including inhibition of angiogenesis, and increases in vascular permeability (153).

\section{A ROLE FOR COMPLEMENT?}

Few studies have examined the possibility of complement involvement in $\mathrm{CD}$ pathogenesis. In early reports, C3 deposits and proteins of the terminal complement pathway were shown in the small intestine, concentrated sub-epithelially and in the lamina propria (37). Untreated CD patients typically have high levels of IgG1 and IgG3 anti-gliadin antibodies in their serum (154) both of which are capable of activating complement (155). Sub-epithelial IgA-TG2 deposits, found in the early stages of CD (156) might also play a role, and polymeric IgA has been shown to activate complement via the MBL pathway (157). Activation of the classical complement pathway would result in increased production of $\mathrm{C} 3 \mathrm{a}$ and $\mathrm{C} 5 \mathrm{a}$, both capable of contributing to the coeliac lesion by increasing vascular permeability and causing mast cell degranulation. In addition, C5a as a chemotactic factor could increase the migration of eosinophils, neutrophils and monocytes to the lesion and initiate release of products such as prostaglandins (142). Complement activation could therefore explain the rapid onset of gluten induced symptoms observed in some patients with $\mathrm{CD}(11,12)$.

\section{A ROLE FOR INTESTINAL MYOFIBROBLASTS?}

Intestinal subepithelial myofibroblasts possess a broad range of biological functions and are likely to play a central role 

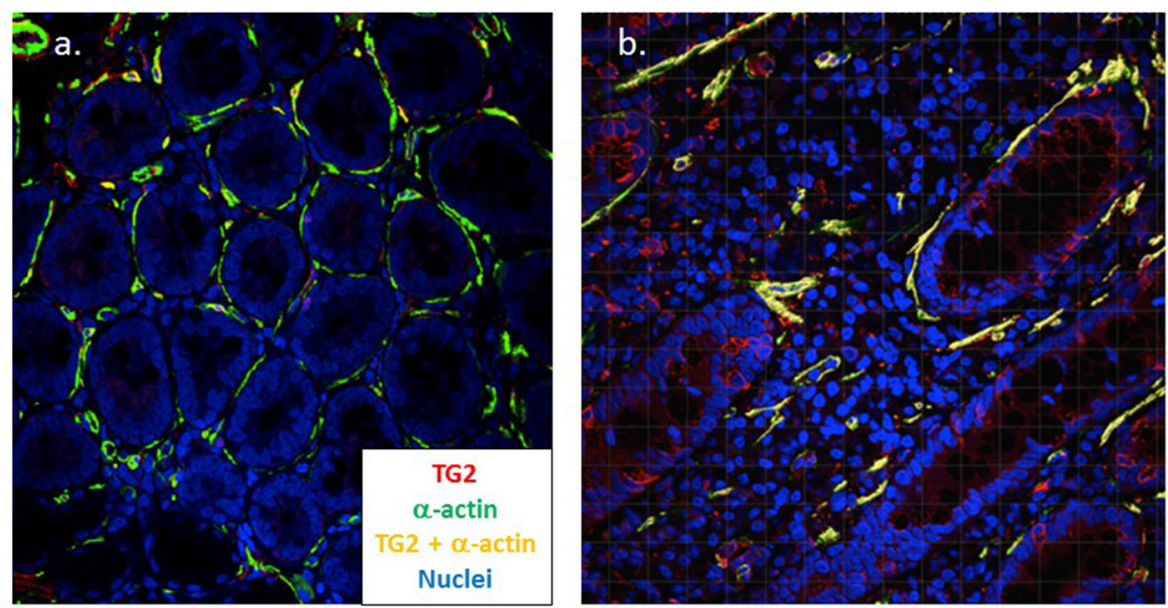

FIGURE 3 | Myofibroblasts strongly co-express TG2 and $\alpha$-actin in coeliac disease. Dual color confocal microscopy demonstrates that intestinal myofibroblasts stain positive for $\alpha$-actin (green) in healthy control tissue $(n=5)$ (a). In active coeliac disease $(n=11)$ (b) these cells upregulate TG2 (red) and significant co-expression is apparent (yellow) (Cooper et al., manuscript in preparation). Original magnification x40.

in architectural remodeling in CD. Myofibroblasts synthesize many components required for the extracellular matrix and the basement membrane and also control the degradation of these structures through the release of matrix metalloproteases (MMPs) along with inhibitors of these enzymes, the tissue inhibitors of metalloproteases (TIMPs) (158). Several studies have described increased mRNA and protein levels of MMP1, MMP-3, MMP-9, MMP-12, and TIMP-1 in the coeliac lesion (159-161). In some instances, levels of MMPs correlated with the degree of histological damage. Several cytokines are critical to the function of myofibroblasts, including TGF$\beta$ (162). In inflammatory bowel disease the production of MMPs by myofibroblasts in is thought to be driven by IL$1 \beta$ and TNF- $\alpha$ (163), and the latter cytokine is produced by IEL in CD (164). IFN $\gamma$ and IL-21 are additional candidate cytokines which may stimulate MMP production in the coeliac lesion $(159,165)$.

In assembling the structure of the small intestine, TG2 plays a central role and myofibroblasts have been shown to strongly express TG2 in active CD (166). Using confocal microscopy, we have confirmed this finding and demonstrated that TG2 expression strongly co-localizes with increased smooth muscle $\alpha$-actin expressed by these cells in active disease (manuscript in preparation) (Figure 3). In an in vitro model, it was found that $\operatorname{IgA}$ autoantibodies to TG2 interfere with the effect of TGF- $\beta$ on myofibroblasts; this resulted in the increased proliferation of enterocytes (151). Finally, myofibroblasts also interact with the immune system, express MHC class II as well as CD80 and CD86, and have been shown to act as non-professional antigen presenting cells (167). It has also been demonstrated that myofibroblasts induce the proliferation and differentiation of regulatory $\mathrm{T}$ cells (168) suggesting a possible role in immune homeostasis.
Taken together, these findings suggest that intestinal myofibroblasts could play an important tissue remodeling role in the coeliac lesion as well as being a potential venue for epitope spreading. The potential contribution of myofibroblasts with multiple cellular and other immune components to $\mathrm{CD}$ pathogenesis is represented in Figure 2B.

\section{CONCLUSION}

Features of CD suggest that it can be considered an autoimmune disease with gluten as an environmental trigger causing activation of a highly specific adaptive immune response. An increase in IELs is a classic finding in CD and some conventional lymphocytes with a NK-like phenotype contribute to enterocyte destruction. The function of other IEL populations, such as $\gamma / \delta$ IELs, in CD is less certain and work to date suggests these cells may play an important local immune regulatory role. Intestinal epithelial cells, through their production of IL15 , play a dynamic role in disease pathogenesis in addition to being targets of the immune response. There is also evidence that cells of the innate immune system, including eosinophils, mast cells and neutrophils, contribute to disease pathogenesis. A further cell population, myofibroblasts, are an important source of TG2 and metalloproteases and therefore may also play a central pathogenic role in CD. Controversy surrounds the issue of whether non-immune gliadin peptides contribute to the disease process. Some studies report that one such peptide, p3143, can cause direct damage to enterocytes and also stimulate enterocyte proliferation. The failure to identify a receptor for this peptide has been used to reject its involvement in the disease process. If alternate gluten peptides cause innate cell activation, this will be important in designing future gluten avoidance strategies. 


\section{AUTHOR CONTRIBUTIONS}

All authors contributed to the planning, writing and editing of this manuscript, and approve this submitted version for publication. $\mathrm{MD}$ and $\mathrm{GB}$ contributed equally to creating the manuscript. Figures were constructed by GB and MD.

\section{REFERENCES}

1. Van De Kamer JH, Weijers HA, Dicke WK. Coeliac disease. IV. An investigation into the injurious constituents of wheat in connection with their action on patients with coeliac disease. Acta Paediatr. (1953) 42:22331. doi: 10.1111/j.1651-2227.1953.tb05586.x

2. Auricchio S, De Ritis G, De Vincenzi M, Silano V. Toxicity mechanisms of wheat and other cereals in celiac disease and related enteropathies. J Pediatr Gastroenterol Nutr. (1985) 4:923-30. doi: 10.1097/00005176-198512000-00012

3. Lundin KE, Scott H, Hansen T, Paulsen G, Halstensen TS, Fausa O, et al. Gliadin-specific, HLA-DQ (alpha $1^{*} 0501$, beta $1^{*} 0201$ ) restricted $\mathrm{T}$ cells isolated from the small intestinal mucosa of celiac disease patients. $J$ Exp Med. (1993) 178:187-96. doi: 10.1084/jem.178.1.187

4. Lundin KE, Sollid LM, Qvigstad E, Markussen G, Gjertsen HA, Ek J, et al. T lymphocyte recognition of a celiac disease-associated cis- or trans-encoded HLA-DQ alpha/beta-heterodimer. J Immunol. (1990) 145:136-9.

5. Gjertsen HA, Lundin KE, Sollid LM, Eriksen JA, Thorsby E. T cells recognize a peptide derived from alpha-gliadin presented by the celiac disease-associated HLA-DQ (alpha $1^{*} 0501$, beta $1^{*} 0201$ ) heterodimer. Hum Immunol. (1994) 39:243-52. doi: 10.1016/0198-8859(94)90267-4

6. van de Wal Y, Kooy YM, Drijfhout JW, Amons R, Koning F. Peptide binding characteristics of the coeliac disease-associated DQ (alpha1*0501, beta $\left.{ }^{*} 0201\right)$ molecule. Immunogenetics. (1996) 44:24653. doi: $10.1007 / \mathrm{s} 002510050120$

7. Vader LW, de Ru A, van der Wal Y, Kooy YMC, Benckhuijsen W, Mearin ML, et al. Specificity of tissue transglutaminase explains cereal toxicity in celiac disease. J Exp Med. (2002) 195:643-9. doi: 10.1084/jem.20012028

8. Dieterich W, Ehnis T, Bauer M, Donner P, Volta U, Riecken EO, et al. Identification of tissue transglutaminase as the autoantigen of celiac disease. Nat Med. (1997) 3:797-801. doi: 10.1038/nm0797-797

9. Lebwohl B, Sanders DS, Green PHR. Coeliac disease. Lancet. (2018) 391:7081. doi: 10.1016/S0140-6736(17)31796-8

10. Ludvigsson JF, Leffler DA, Bai JC, Biagi F, Fasano A, Green PHR, et al. The Oslo definitions for coeliac disease and related terms. Gut. (2013) 62:43-52. doi: 10.1136/gutjnl-2011-301346

11. Bruins MJ. The clinical response to gluten challenge: a review of the literature. Nutrients. (2013) 5:4614-41. doi: 10.3390/nu5114614

12. Laurin P, Wolving M, Fälth-Magnusson K. Even small amounts of gluten cause relapse in children with celiac disease. J Pediatr Gastroenterol Nutr. (2002) 34:26-30. doi: 10.1097/00005176-200201000-00007

13. Barratt SM, Leeds JS, Sanders DS. Factors influencing the type, timing and severity of symptomatic responses to dietary gluten in patients with biopsy-proven coeliac disease. J Gastrointestin Liver Dis. (2013) 22:391-6.

14. Collin P, Vilppula A, Luostarinen L, Holmes GKT, Kaukinen K. Review article: coeliac disease in later life must not be missed. Aliment Pharmacol Ther. (2018) 47:563-72. doi: 10.1111/apt.14490

15. Ludvigsson JF, Rubio-Tapia A, van Dyke CT, Melton LJ, Zinsmeister AR, Lahr BD, et al. Increasing incidence of celiac disease in a north American population. Am J Gastroenterol. (2013) 108:818-24. doi: 10.1038/ajg.2013.60

16. Järvinen TT, Collin $\mathrm{P}$, Rasmussen $\mathrm{M}$, Kyrönpalo $\mathrm{S}$, Mäki $\mathrm{M}$, Partanen J, et al. Villous tip intraepithelial lymphocytes as markers of early-stage coeliac disease. Scand J Gastroenterol. (2004) 39:428-33. doi: 10.1080/00365520310008773

17. Marsh MN. Gluten, major histocompatibility complex, and the small intestine. A molecular and immunobiologic approach to the spectrum
ACKNOWLEDGMENTS

We thank Dr. Sarah Cooper and Dr. Jean Dunne for their work on the confocal imaging of intestinal myofibroblasts in the coeliac lesion. We would also like to express our gratitude to Sharon Wilson for her organ culture work concerning the effects of gliadin on enterocyte cytoskeletal proteins.

of gluten sensitivity ('celiac sprue'). Gastroenterology. (1992) 102:33054. doi: 10.1016/0016-5085(92)91819-P

18. Oberhuber G, Granditsch G, Vogelsang H. The histopathology of coeliac disease: time for a standardized report scheme for pathologists. Eur J Gastroenterol Hepatol. (1999) 11:118594. doi: 10.1097/00042737-199910000-00019

19. Lundin KEA, Wijmenga C. Coeliac disease and autoimmune disease genetic overlap and screening. Nat Rev Gastroenterol Hepatol. (2015) 12:50715. doi: 10.1038/nrgastro.2015.136

20. Krishnareddy S. The microbiome in celiac disease. Gastroenterol Clin North Am. (2019) 48:115-126. doi: 10.1016/j.gtc.2018.09.008

21. Mayassi T, Ladell K, Gudjonson H, McLaren JE, Shaw DG, Tran MT, et al. Chronic inflammation permanently reshapes tissue-resident immunity in celiac disease. Cell. (2019) 176:967-81.e19. doi: 10.1016/j.cell.2018.12.039

22. Eggesbø LM, Risnes LF, Neumann RS, Lundin KEA, Christophersen A, Sollid LM. Single-cell TCR sequencing of gut intraepithelial $\gamma \delta$ T cells reveals a vast and diverse repertoire in celiac disease. Mucosal Immunol. (2019) 13:313-21. doi: 10.1038/s41385-019-0222-9

23. Dunne MR, Elliott L, Hussey S, Mahmud N, Kelly J, Doherty DGDG, et al. Persistent changes in circulating and intestinal $\gamma \delta \mathrm{T}$ cell subsets, invariant natural killer $\mathrm{T}$ cells and mucosal-associated invariant $\mathrm{T}$ cells in children and adults with coeliac disease. PLOS ONE. (2013) 8:e76008. doi: 10.1371/journal.pone.0076008

24. Syage JA, Kelly CP, Dickason MA, Ramirez AC, Leon F, Dominguez R, et al. Determination of gluten consumption in celiac disease patients on a glutenfree diet. Am J Clin Nutr. (2018) 107:201-207. doi: 10.1093/ajcn/nqx049

25. Koning F. Pathophysiology of celiac disease. TL - 59 Suppl 1. J Pediatr Gastroenterol Nutr. (2014) 59 (Suppl 1) :S14. doi: 10.1097/01.mpg.0000450391.46027.48

26. Olazagoitia-Garmendia A, Santin I, Castellanos-Rubio A. Functional implication of celiac disease associated lncRNAs in disease pathogenesis. Comput Biol Med. (2018) 102:36975. doi: 10.1016/j.compbiomed.2018.08.013

27. Dieli-Crimi R, Cénit MC, Núñez C. The genetics of celiac disease: a comprehensive review of clinical implications. J Autoimmun. (2015) 64:2641. doi: 10.1016/j.jaut.2015.07.003

28. Maiuri L, Ciacci C, Ricciardelli I, Vacca L, Raia V, Auricchio $\mathrm{S}$, et al. Association between innate response to gliadin and activation of pathogenic $\mathrm{T}$ cells in coeliac disease. Lancet. (2003) 362:30-7. doi: 10.1016/S0140-6736(03)13803-2

29. Barone MV, Troncone R, Auricchio S. Gliadin peptides as triggers of the proliferative and stress/innate immune response of the celiac small intestinal mucosa. Int J Mol Sci. (2014) 15:20518-37. doi: 10.3390/ijms151120518

30. Kim SM, Mayassi T, Jabri B. Innate immunity: actuating the gears of celiac disease pathogenesis. Best Pract Res Clin Gastroenterol. (2015) 29:42535. doi: 10.1016/j.bpg.2015.05.001

31. Hällgren R, Colombel JF, Dahl R, Fredens K, Kruse A, Jacobsen NO, et al. Neutrophil and eosinophil involvement of the small bowel in patients with celiac disease and crohn's disease: studies on the secretion rate and immunohistochemical localization of granulocyte granule constituents. Am J Med. (1989) 86:56-64. doi: 10.1016/0002-9343(89)90230-1

32. Marsh MN, Hinde J. Inflammatory component of celiac sprue mucosa. I. Mast cells, basophils, and eosinophils. Gastroenterology. (1985) 89:92101. doi: 10.1016/0016-5085(85)90749-8

33. Desreumaux P, Janin A, Colombel JF, Prin L, Plumas J, Emilie D, et al. Interleukin 5 messenger RNA expression by eosinophils in the intestinal 
mucosa of patients with coeliac disease. J Exp Med. (1992) 175:2936. doi: $10.1084 / \mathrm{jem} .175 .1 .293$

34. Colombel JF, Torpier G, Janin A, Klein O, Cortot A, Capron M. Activated eosinophils in adult coeliac disease: Evidence for a local release of major basic protein. Gut. (1992) 33:1190-1194. doi: 10.1136/gut.33.9.1190

35. Strobel S, Busuttil A, Ferguson A. Human intestinal mucosal mast cells: expanded population in untreated coeliac disease. Gut. (1983) 24:2227. doi: $10.1136 /$ gut.24.3.222

36. Frossi B, Tripodo C, Guarnotta C, Carroccio A, De Carli M, De Carli S, et al. Mast cells are associated with the onset and progression of celiac disease. J Allergy Clin Immunol. (2017) 139:1266-274.e1. doi: 10.1016/j.jaci.2016.08.011

37. Halstensen TS, Hvatum M, Scott H, Fausa O, Brandtzaeg P. Association of subepithelial deposition of activated complement and immunoglobulin $\mathrm{G}$ and $\mathrm{M}$ response to gluten in celiac disease. Gastroenterology. (1992) 102:751-9. doi: 10.1016/0016-5085(92)90155-R

38. Ciclitira PJ, Evans DJ, Fagg NL, Lennox ES, Dowling RH. Clinical testing of gliadin fractions in coeliac patients. Clin Sci. (1984) 66:35764. doi: 10.1042/cs0660357

39. Sturgess R, Day P, Ellis HJ, Lundin KE, Gjertsen HA, Kontakou M, et al. Wheat peptide challenge in coeliac disease. Lancet. (1994) 343:75861. doi: 10.1016/S0140-6736(94)91837-6

40. Maiuri L, Ciacci C, Raia V, Vacca L, Ricciardelli I, Raimondi F, et al. FAS engagement drives apoptosis of enterocytes of coeliac patients. Gut. (2001) 48:418-24. doi: 10.1136/gut.48.3.418

41. Mazzarella G, Stefanile R, Camarca A, Giliberti P, Cosentini E, Marano C, et al. Gliadin activates HLA class I-restricted CD8+ T cells in celiac disease intestinal mucosa and induces the enterocyte apoptosis. Gastroenterology. (2008) 134:1017-27. doi: 10.1053/j.gastro.2008.01.008

42. Londei M, Ciacci C, Ricciardelli I, Vacca L, Quaratino S, Maiuri L. Gliadin as a stimulator of innate responses in celiac disease. Mol Immunol. (2005) 42:913-8. doi: 10.1016/j.molimm.2004.12.005

43. Maiuri L, Picarelli A, Boirivant M, Coletta S, Mazzilli M, De Vincenzi M, et al. Definition of the initial immunologic modifications upon in vitro gliadin challenge in the small intestine of celiac patients. Gastroenterology. (1996) 110:1368-78. doi: 10.1053/gast.1996.v110.pm8613040

44. Gajendran M, Loganathan P, Catinella AP, Hashash JG. A comprehensive review and update on Crohn's disease. Disease-a-Month. (2018) 64:2057. doi: 10.1016/j.disamonth.2017.07.001

45. Hüe S, Mention J-J, Monteiro RC, Zhang S, Cellier C, Schmitz J, et al. A direct role for NKG2D/MICA interaction in villous atrophy during celiac disease. Immunity. (2004) 21:367-77. doi: 10.1016/j.immuni.2004.06.018

46. Meresse B, Chen Z, Ciszewski C, Tretiakova M, Bhagat G, Krausz TN, et al. Coordinated induction by IL15 of a TCR-independent NKG2D signaling pathway converts CTL into lymphokine-activated killer cells in celiac disease. Immunity. (2004) 21:357-66. doi: 10.1016/j.immuni.2004.06.020

47. Biagi F, Luinetti O, Campanella J, Klersy C, Zambelli C, Villanacci V, et al. Intraepithelial lymphocytes in the villous tip: do they indicate potential coeliac disease? J Clin Pathol. (2004) 57:835-9. doi: 10.1136/jcp.2003.013607

48. Collin P, Salmi TT, Hervonen K, Kaukinen K, Reunala T. Dermatitis herpetiformis: a cutaneous manifestation of coeliac disease. Ann Med. (2017) 49:23-31. doi: 10.1080/07853890.2016.1222450

49. Myrsky E, Caja S, Simon-Vecsei Z, Korponay-Szabo IR, Nadalutti C, Collighan $\mathrm{R}$, et al. Celiac disease IgA modulates vascular permeability in vitro through the activity of transglutaminase 2 and RhoA. Cell Mol Life Sci. (2009) 66:3375-85. doi: 10.1007/s00018-009-0116-1

50. Marsh MN, Heal CJ. Evolutionary developments in interpreting the gluteninduced mucosal celiac lesion: an archimedian heuristic. Nutrients. (2017) 9:213 doi: 10.3390/nu9030213

51. Leon F. Flow cytometry of intestinal intraepithelial lymphocytes in celiac disease. J Immunol Methods. (2011) 363:17786. doi: $10.1016 /$ j.jim.2010.09.002

52. Nijeboer P, van Gils T, Reijm M, Ooijevaar R, Lissenberg-Witte BI, Bontkes HJ, et al. Gamma-Delta $\mathrm{T}$ Lymphocytes in the diagnostic approach of coeliac disease. J Clin Gastroenterol. (2019) 53:e208e13. doi: 10.1097/MCG.0000000000001060

53. Fernández-Bañares F, Crespo L, Núñez C, López-Palacios N, Tristán E, Vivas S, et al. Gamma delta+ intraepithelial lymphocytes and coeliac lymphogram in a diagnostic approach to coeliac disease in patients with seronegative villous atrophy. Aliment Pharmacol Ther. (2020) 51:699705. doi: $10.1111 /$ apt.15663

54. Cooke WT, Holmes GKT. Coeliac Disease. New York, NY: Churchill Livingstone (1984) .

55. Mohamed BM, Feighery C, Williams Y, Davies A, Kelleher D, Volkov Y, et al. The use of cellomics to study enterocyte cytoskeletal proteins in coeliac disease patients. Cent Eur J Biol. (2008) 3:258-67. doi: 10.2478/s11535-008-0029-2

56. Holmes G, Catassi C. Coeliac Disease (Fast Facts) 1st ed. Oxford: Health Pr. (2000) .

57. Moss SF, Attia L, Scholes J V, Walters JR, Holt PR. Increased small intestinal apoptosis in coeliac disease. Gut. (1996) 39:811-7. doi: 10.1136/gut.39.6.811

58. Das P, Gahlot GPS, Mehta R, Makharia A, Verma AK, Sreenivas V, et al. Patients with mild enteropathy have apoptotic injury of enterocytes similar to that in advanced enteropathy in celiac disease. Dig Liver Dis. (2016) 48:1290-5. doi: 10.1016/j.dld.2016.06.013

59. Ciccocioppo R, Di Sabatino A, Parroni R, Muzi P, D’Alò S, Ventura T, et al. Increased enterocyte apoptosis and fas-fas ligand system in celiac disease. $A m$ J Clin Pathol. (2001) 115:494-503. doi: 10.1309/UV54-BHP3-A66B-0QUD

60. Adriaanse MPM, Tack GJ, Passos VL, Damoiseaux JGMC, Schreurs MWJ, van Wijck K, et al. Serum I-FABP as marker for enterocyte damage in coeliac disease and its relation to villous atrophy and circulating autoantibodies. Aliment Pharmacol Ther. (2013) 37:482-90. doi: 10.1111/apt.12194

61. Adriaanse MPM, Leffler DA, Kelly CP, Schuppan D, Najarian RM, Goldsmith JD, et al. Serum I-FABP detects gluten responsiveness in adult celiac disease patients on a short-term gluten challenge. Am J Gastroenterol. (2016) 111:1014-22. doi: 10.1038/ajg.2016.162

62. Hoffmanová I, Sánchez D, Hábová V, Anděl M, Tučková L, Tlaskalová-Hogenová H. Serological markers of enterocyte damage and apoptosis in patients with celiac disease, autoimmune diabetes mellitus and diabetes mellitus type 2. Physiol Res. (2015) 64:537-46. doi: 10.33549/physiolres.932916

63. Adriaanse MPM, Mubarak A, Riedl RG, Ten Kate FJW, Damoiseaux JGMC, Buurman WA, et al. Progress towards non-invasive diagnosis follow-up of celiac disease in children; a prospective multicentre study to the usefulness of plasma I-FABP. Sci Rep. (2017) 7:8671. doi: 10.1038/s41598-017-07242-4

64. Bottasso Arias NM, García M, Bondar C, Guzman L, Redondo A, Chopita $\mathrm{N}$, et al. Expression pattern of fatty acid binding proteins in celiac disease enteropathy. Mediators Inflamm. (2015) 2015:738563. doi: 10.1155/2015/738563

65. Allaire JM, Crowley SM, Law HT, Chang SY, Ko HJ, Vallance BA. The intestinal epithelium: central coordinator of mucosal immunity. Trends Immunol. (2018) 39:677-96. doi: 10.1016/j.it.2018.04.002

66. Peterson LW, Artis D. Intestinal epithelial cells: regulators of barrier function and immune homeostasis. Nat Rev Immunol. (2014) 14:14153. doi: $10.1038 /$ nri3608

67. Burgueño JF, Abreu MT. Epithelial toll-like receptors and their role in gut homeostasis and disease. Nat Rev Gastroenterol Hepatol. (2020) 17:26378. doi: 10.1038/s41575-019-0261-4

68. Abadie V, Jabri B. IL-15: A central regulator of celiac disease immunopathology. Immunol Rev. (2014) 260:22134. doi: 10.1111/imr.12191

69. Wang W, Uzzau S, Goldblum SE, Fasano A. Human zonulin, a potential modulator of intestinal tight junctions. J Cell Sci. (2000) 113:4435-40.

70. Fluge G, Aksnes L. Morphological and morphometric assessment of human duodenal biopsies maintained in organ culture. In vitro influences of gluten in coeliac disease. Scand J Gastroenterol. (1981) 16:55567. doi: $10.3109 / 00365528109182012$

71. Howdle PD, Corazza GR, Bullen AW, Losowsky MS. In vitro diagnosis of coeliac disease: an assessment. Gut. (1981) 22:939-47. doi: 10.1136/gut.22.11.939

72. Shidrawi RG, Day P, Przemioslo R, Ellis HJ, Nelufer JM, Ciclitira PJ. In vitro toxicity of gluten peptides in coeliac disease assessed by organ culture. Scand J Gastroenterol. (1995) 30:758-63. doi: 10.3109/00365529509 096324

73. Stenman SM, Lindfors K, Korponay-Szabo IR, Lohi O, Saavalainen P, Partanen J, et al. Secretion of celiac disease autoantibodies after in vitro 
gliadin challenge is dependent on small-bowel mucosal transglutaminase 2specific IgA deposits. BMC Immunol. (2008) 9:6. doi: 10.1186/1471-2172-9-6

74. Maiuri L, Ciacci C, Auricchio S, Brown V, Quaratino S, Londei M. Interleukin 15 mediates epithelial changes in celiac disease. Gastroenterology. (2000) 119:996-1006. doi: 10.1053/gast.2000.18149

75. Maiuri L, Ciacci C, Vacca L, Ricciardelli I, Auricchio S, Quaratino S, et al. IL-15 drives the specific migration of CD94+ and TCR-gammadelta+ intraepithelial lymphocytes in organ cultures of treated celiac patients. Am J Gastroenterol. (2001) 96:150-6. doi: 10.1111/j.1572-0241.2001.03437.x

76. Wilson S, Volkov Y, Feighery C. Rearrangement of enterocyte cytoskeletal proteins in coeliac disease. Endoscopy. (2004) 36:36-46. doi: 10.1055/s-2004-825028

77. Freedman AR, Macartney JC, Nelufer JM, Ciclitira PJ. Timing of infiltration of Tlymphocytes induced by gluten into the small intestine in coeliac disease. J Clin Pathol. (1987) 40:741-5. doi: 10.1136/jcp.40.7.741

78. Dewar DH, Amato M, Ellis HJ, Pollock EL, Gonzalez-Cinca N, Wieser H, et al. The toxicity of high molecular weight glutenin subunits of wheat to patients with coeliac disease. Eur J Gastroenterol Hepatol. (2006) 18:4839. doi: 10.1097/00042737-200605000-00005

79. Fraser JS, Engel W, Ellis HJ, Moodie SJ, Pollock EL, Wieser H, et al. Coeliac disease: in vivo toxicity of the putative immunodominant epitope. Gut. (2003) 52:1698-702. doi: 10.1136/gut.52.12.1698

80. Goel G, Tye-din JA, Qiao S, Russell AK, Mayassi T, Ciszewski C, et al. Cytokine release and gastrointestinal symptoms after gluten challenge in celiac disease. Immunology. (2019) 5:eaaw7756. doi: 10.1126/sciadv.aaw7756

81. Booth CC. Enterocyte in coeliac disease. 1. Br Med J. (1970) 3:72531. doi: $10.1136 / \mathrm{bmj} .3 .5725 .725$

82. Wright N, Watson A, Morley A, Appleton D, Marks J, Douglas A. The cell cycle time in the flat (avillous) mucosa of the human small intestine. Gut. (1973) 14:603-6. doi: 10.1136/gut.14.8.603

83. Wright N, Watson A, Morley A, Appleton D, Marks J. Cell kinetics in flat (avillous) mucosa of the human small intestine. Gut. (1973) 14:70110. doi: 10.1136/gut.14.9.701

84. Nanayakkara M, Lania G, Maglio M, Auricchio R, De Musis C, Discepolo V, et al. P31-43, an undigested gliadin peptide, mimics and enhances the innate immune response to viruses and interferes with endocytic trafficking: a role in celiac disease. Sci Rep. (2018) 8:10821. doi: 10.1038/s41598-018-28830-y

85. Barone MV, Gimigliano A, Castoria G, Paolella G, Maurano F, Paparo F, et al. Growth factor-like activity of gliadin, an alimentary protein: implications for coeliac disease. Gut. (2007) 56:480-8. doi: 10.1136/gut.2005.086637

86. Barone MV, Zanzi D, Maglio M, Nanayakkara M, Santagata S, Lania G, et al. Gliadin-mediated proliferation and innate immune activation in celiac disease are due to alterations in vesicular trafficking. PLoS ONE. (2011) 6:e17039. doi: 10.1371/journal.pone.0017039

87. Maiuri L, Ciacci C, Ricciardelli I, Vacca L, Raia V, Rispo A, et al. Unexpected role of surface transglutaminase type II in celiac disease. Gastroenterology. (2005) 129:1400-13. doi: 10.1053/j.gastro.2005.07.054

88. Villella VR, Venerando A, Cozza G, Esposito S, Ferrari E, Monzani R, et al. A pathogenic role for cystic fibrosis transmembrane conductance regulator in celiac disease. EMBO J. (2019) 38:e100101. doi: 10.15252/embj.2018100101

89. Herrera MG, Gómez Castro MF, Prieto E, Barrera E, Dodero VI, Pantano $\mathrm{S}$, et al. Structural conformation and self-assembly process of $\mathrm{p} 31-43$ gliadin peptide in aqueous solution. Implications for celiac disease. FEBS J. (2019) 287:2134-49. doi: 10.1111/febs.15109

90. Gómez Castro MF, Miculán E, Herrera MG, Ruera C, Perez F, Prieto ED, et al. p31-43 gliadin peptide forms oligomers and induces NLRP3 inflammasome/caspase 1- dependent mucosal damage in small intestine. Front Immunol. (2019) 10:31. doi: 10.3389/fimmu.2019.00031

91. Araya RE, Gomez Castro MF, Carasi P, McCarville JL, Jury J, Mowat AM, et al. Mechanisms of innate immune activation by gluten peptide p31-43 in mice. Am J Physiol Liver Physiol. (2016) 311:G40-G49. doi: 10.1152/ajpgi.00435.2015

92. Monteleone G, Pender SL, Alstead E, Hauer AC, Lionetti P, McKenzie $\mathrm{C}$, et al. Role of interferon alpha in promoting $\mathrm{T}$ helper cell type 1 responses in the small intestine in coeliac disease. Gut. (2001) 48:4259. doi: 10.1136/gut.48.3.425

93. Bouziat R, Biering SB, Kouame E, Sangani KA, Kang S, Ernest JD, et al. Murine norovirus infection induces TH1 inflammatory responses to dietary antigens. Cell Host Microbe. (2018) 24:677-88.e5. doi: 10.1016/j.chom.2018.10.004

94. Caminero A, Galipeau HJ, McCarville JL, Johnston CW, Bernier SP, Russell AK, et al. Duodenal bacteria from patients with celiac disease and healthy subjects distinctly affect gluten breakdown and immunogenicity. Gastroenterology. (2016) 151:670-83. doi: 10.1053/j.gastro.2016.06.041

95. Junker Y, Zeissig S, Kim S-J, Barisani D, Wieser H, Leffler DA, et al. Wheat amylase trypsin inhibitors drive intestinal inflammation via activation of tolllike receptor 4. J Exp Med. (2012) 209:2395-408. doi: 10.1084/jem.20102660

96. Escudero-Hernández C, Martín Á, Pedro Andrés R, Fernández-Salazar L, Garrote JA, Bernardo D, et al. Circulating dendritic cells from celiac disease patients display a gut-homing profile and are differentially modulated by different gliadin-derived peptides. Mol Nutr Food Res. (2020) 64:1900989. doi: 10.1002/mnfr.201900989

97. Brandtzaeg P. The changing immunological paradigm in coeliac disease. Immunol Lett. (2006) 105:127-39. doi: 10.1016/j.imlet.2006. 03.004

98. Høydahl LS, Richter L, Frick R, Snir O, Gunnarsen KS, Landsverk OJB, et al. Plasma cells are the most abundant gluten peptide MHC-expressing cells in inflamed intestinal tissues from patients with celiac disease. Gastroenterology. (2019) 156:1428-39.e10. doi: 10.1053/j.gastro.2018.12.013

99. Bondar C, Araya RE, Guzman L, Rua EC, Chopita N, Chirdo FG. Role of CXCR3/CXCL10 axis in immune cell recruitment into the small intestine in celiac disease. PLoS ONE. (2014) 9:e89068. doi: 10.1371/journal.pone.0089068

100. Molberg O, Kett K, Scott H, Thorsby E, Sollid LM, Lundin KE. Gliadin specific, HLA DQ2-restricted T cells are commonly found in small intestinal biopsies from coeliac disease patients, but not from controls. Scand $J$ Immunol. (1997) 46:103-8. doi: 10.1046/j.1365-3083.1997.d01-93.x

101. Bodd M, Ráki M, Bergseng E, Jahnsen J, Lundin KEA, Sollid LM. Direct cloning and tetramer staining to measure the frequency of intestinal gluten-reactive T cells in celiac disease. Eur J Immunol. (2013) 43:260512. doi: 10.1002/eji.201343382

102. Nilsen EM, Lundin KE, Krajci P, Scott H, Sollid LM, Brandtzaeg P. Gluten specific, HLA-DQ restricted T cells from coeliac mucosa produce cytokines with Th1 or Th0 profile dominated by interferon gamma. Gut. (1995) 37:766-76. doi: 10.1136/gut.37.6.766

103. Mazzarella G. Effector and suppressor T cells in celiac disease. World J Gastroenterol. (2015) 21:7349. doi: 10.3748/wjg.v21.i24.7349

104. Black KE, Murray JA, David CS. HLA-DQ determines the response to exogenous wheat proteins: a model of gluten sensitivity in transgenic knockout mice. J Immunol. (2002) 169:5595-600. doi: 10.4049/jimmunol.169.10.5595

105. de Kauwe AL, Chen Z, Anderson RP, Keech CL, Price JD, Wijburg O, et al. Resistance to celiac disease in humanized HLA-DR3-DQ2-transgenic mice expressing specific anti-gliadin CD4+ T cells. J Immunol. (2009) 182:744050. doi: 10.4049/jimmunol.0900233

106. Setty M, Discepolo V, Abadie V, Kamhawi S, Mayassi T, Kent A, et al. Distinct and synergistic contributions of epithelial stress and adaptive immunity to functions of intraepithelial killer cells and active celiac disease. Gastroenterology. (2015) 149:681-91.e10. doi: 10.1053/j.gastro.2015.05.013

107. Troncone R, Greco L, Mayer M, Paparo F, Caputo N, Micillo M, et al. Latent and potential coeliac disease. Acta Paediatr Suppl. (1996) 412:104. doi: 10.1111/j.1651-2227.1996.tb14240.x

108. Marsh MN. Screening for latent gluten sensitivity: questions many, but answers few. Eur J Gastroenterol Hepatol. (1996) 8:3-6. doi: 10.1097/00042737-199601000-00002

109. Di Sabatino A, Ciccocioppo R, Cupelli F, Cinque B, Millimaggi D, Clarkson $\mathrm{MM}$, et al. Epithelium derived interleukin 15 regulates intraepithelial lymphocyte Th1 cytokine production, cytotoxicity, and survival in coeliac disease. Gut. (2006) 55:469-77. doi: 10.1136/gut.2005.068684

110. Allegretti YL, Bondar C, Guzman L, Cueto Rua E, Chopita N, Fuertes $M$, et al. Broad MICA/B expression in the small bowel mucosa: a link between cellular stress and celiac disease. PLoS ONE. (2013) 8:e73658. doi: 10.1371/journal.pone.0073658

111. Abadie V, Kim SM, Lejeune T, Palanski BA, Ernest JD, Tastet O, et al. IL15, gluten and HLA-DQ8 drive tissue destruction in coeliac disease. Nature. (2020) 578:600-4. doi: 10.1038/s41586-020-2003-8 
112. Jabri B, Sollid LM.T cells in celiac disease. J Immunol. (2017) 198:300514. doi: 10.4049 /jimmunol.1601693

113. Mayassi T, Jabri B. Human intraepithelial lymphocytes. Mucosal Immunol. (2018) 11:1281-9. doi: 10.1038/s41385-018-0016-5

114. Kilmartin C, Lynch S, Abuzakouk M, Wieser H, Feighery C. Avenin fails to induce a Th1 response in coeliac tissue following in vitro culture. Gut. (2003) 52:47-52. doi: 10.1136/gut.52.1.47

115. Bodd M, Ráki M, Tollefsen S, Fallang LE, Bergseng E, Lundin KEA, et al. HLA-DQ2-restricted gluten-reactive T cells produce IL-21 but not IL-17 or IL-22. Mucosal Immunol. (2010) 3:594-601. doi: 10.1038/mi.2010.36

116. van Leeuwen MA, Lindenbergh-Kortleve DJ, Raatgeep HC, de Ruiter LF, de Krijger RR, Groeneweg M, et al. Increased production of interleukin-21, but not interleukin-17A, in the small intestine characterizes pediatric celiac disease. Mucosal Immunol. (2013) 6:1202-13. doi: 10.1038/mi.2013.19

117. Ciszewski C, Discepolo V, Pacis A, Doerr N, Tastet O, Mayassi T, et al. Identification of a $\gamma c$ receptor antagonist that prevents reprogramming of human tissue-resident cytotoxic T cells by IL15 and IL21. Gastroenterology. (2020) 158:625-37.e13. doi: 10.1053/j.gastro.2019.10.006

118. Verdu EF, Galipeau HJ, Jabri B. Novel players in coeliac disease pathogenesis: role of the gut microbiota. Nat Rev Gastroenterol Hepatol. (2015) 12:497506. doi: 10.1038/nrgastro.2015.90

119. Bouziat R, Hinterleitner R, Brown JJ, Stencel-Baerenwald JE, Ikizler M, Mayassi $\mathrm{T}$, et al. Reovirus infection triggers inflammatory responses to dietary antigens and development of celiac disease. Science. (2017) 356:4450. doi: $10.1126 /$ science.aah5298

120. Plot L, Amital H. Infectious associations of celiac disease. Autoimmun Rev. (2009) 8:316-9. doi: 10.1016/j.autrev.2008.10.001

121. Petersen J, Ciacchi L, Tran MT, Loh KL, Kooy-Winkelaar Y, Croft $\mathrm{NP}$, et al. $\mathrm{T}$ cell receptor cross-reactivity between gliadin and bacterial peptides in celiac disease. Nat Struct Mol Biol. (2020) 27:49-61. doi: 10.1038/s41594-019-0353-4

122. Cheroutre H, Lambolez F, Mucida D. The light and dark sides of intestinal intraepithelial lymphocytes. Nat Rev Immunol. (2011) 11:44556. doi: $10.1038 /$ nri3007

123. Tjon JM-L, Kooy-Winkelaar YMC, Tack GJ, Mommaas AM, Schreurs MWJ, Schilham MW, et al. DNAM-1 mediates epithelial cell-specific cytotoxicity of aberrant intraepithelial lymphocyte lines from refractory celiac disease type II patients. J Immunol. (2011) 186:6304-12. doi: 10.4049/jimmunol.1003382

124. Kutlu T, Brousse N, Rambaud C, Le Deist F, Schmitz J, Cerf-Bensussan $\mathrm{N}$. Numbers of T cell receptor (TCR) alpha beta+ but not of TcR gamma delta+ intraepithelial lymphocytes correlate with the grade of villous atrophy in coeliac patients on a long term normal diet. Gut. (1993) 34:20814. doi: $10.1136 /$ gut.34.2.208

125. Hayday A, Tigelaar R. Immunoregulation in the tissues by gammadelta $\mathrm{T}$ cells. Nat Rev Immunol. (2003) 3:233-42. doi: 10.1038/nri1030

126. Nielsen MM, Witherden DA, Havran WL. $\gamma \delta \mathrm{T}$ cells in homeostasis and host defence of epithelial barrier tissues. Nat Rev Immunol. (2017) 17:73345. doi: 10.1038/nri.2017.101

127. Rust C, Kooy Y, Peña S, Mearin ML, Kluin P, Koning F. Phenotypical and functional characterization of small intestinal TcR gamma delta $+\mathrm{T}$ cells in coeliac disease. Scand J Immunol. (1992) 35:459-68. doi: 10.1111/j.1365-3083.1992.tb02881.x

128. Trejdosiewicz LK, Calabrese A, Smart CJ, Oakes DJ, Howdle PD, Crabtree JE, et al. Gamma delta $\mathrm{T}$ cell receptor-positive cells of the human gastrointestinal mucosa: occurrence and $\mathrm{V}$ region gene expression in heliobacter pyloriassociated gastritis, coeliac disease and inflammatory bowel disease. Clin Exp Immunol. (1991) 84:440-4.

129. De Libero G, Rocci MP, Casorati G, Giachino C, Oderda G, Tavassoli K, et al. $\mathrm{T}$ cell receptor heterogeneity in gamma delta $\mathrm{T}$ cell clones from intestinal biopsies of patients with celiac disease. Eur J Immunol. (1993) 23:499-504. doi: 10.1002/eji.1830230230

130. Halstensen TS, Scott H, Brandtzaeg P. Intraepithelial $T$ cells of the TcR gamma/delta+ CD8- and $\mathrm{V}$ delta $1 / \mathrm{J}$ delta $1+$ phenotypes are increased in coeliac disease. Scand J Immunol. (1989) 30:665-72. doi: 10.1111/j.1365-3083.1989.tb02474.x

131. Siegers GM, Lamb LS. Cytotoxic and regulatory properties of circulating $\mathrm{V} \delta 1+\gamma \delta \mathrm{T}$ cells: a new player on the cell therapy field? Mol Ther. (2014) 22:1416-22. doi: 10.1038/mt.2014.104
132. Toulon A, Breton L, Taylor KR, Tenenhaus M, Bhavsar D, Lanigan C, et al. A role for human skin-resident T cells in wound healing. J Exp Med. (2009) 206:743-50. doi: 10.1084/jem.20081787

133. Bhagat G, Naiyer AJ, Shah JG, Harper J, Jabri B, Wang TC, et al. Small intestinal CD8+TCRgammadelta+NKG2A+ intraepithelial lymphocytes have attributes of regulatory cells in patients with celiac disease. JClin Invest. (2008) 118:281-93. doi: 10.1172/JCI30989

134. Zhang $\mathrm{S}$. The role of transforming growth factor $\beta$ in $\mathrm{T}$ helper 17 differentiation. Immunology. (2018) 155:24-35. doi: 10.1111/imm.12938

135. Zaiatz-Bittencourt V, Finlay DK, Gardiner CM. Canonical TGF- $\beta$ signaling pathway represses human NK cell metabolism. J Immunol. (2018) 200:393441. doi: 10.4049/jimmunol.1701461

136. Marafini I, Imeneo MG, Monteleone G. The role of natural killer receptors in celiac disease. Immunome Res. (2017) 13:22906039 doi: 10.4172/1745-7580.10000129

137. Dhesi I, Marsh MN, Kelly C, Crowe P. Morphometric analysis of small intestinal mucosa. II. Determination of lamina propria volumes; plasma cell and neutrophil populations within control and coeliac disease mucosae. Virchows Arch A Pathol Anat Histopathol. (1984) 403:17380. doi: 10.1007/BF00695233

138. Marsh MN, Crowe PT. Morphology of the mucosal lesion in gluten sensitivity. Baillieres Clin Gastroenterol. (1995) 9:273-93. doi: 10.1016/0950-3528(95)90032-2

139. Rescigno M, Di Sabatino A. Dendritic cells in intestinal homeostasis and disease. J Clin Invest. (2009) 119:2441-50. doi: 10.1172/JCI39134

140. Beitnes A-CR, Ráki M, Brottveit M, Lundin KEA, Jahnsen FL, Sollid LM. Rapid accumulation of $\mathrm{CD} 14+\mathrm{CD} 11 \mathrm{c}+$ dendritic cells in gut mucosa of celiac disease after in vivo gluten challenge. PLoS ONE. (2012) 7:e33556. doi: 10.1371/journal.pone.0033556

141. Lavo B, Knutson L, Lööf L, Odlind B, Venge P, Hällgren R. Challenge with gliadin induces eosinophil and mast cell activation in the jejunum of patients with celiac disease. Am J Med. (1989) 87:655-60. doi: 10.1016/S0002-9343(89)80399-7

142. Lavö B, Knutson L, Lööf L, Hällgren R. Gliadin challenge-induced jejunal prostaglandin E2 secretion in celiac disease. Gastroenterology. (1990) 99:7037. doi: 10.1016/0016-5085(90)90958-4

143. Diosdado B, van Bakel H, Strengman E, Franke L, van Oort E, Mulder CJ, et al. Neutrophil recruitment and barrier impairment in celiac disease: a genomic study. Clin Gastroenterol Hepatol. (2007) 5:57481. doi: 10.1016/j.cgh.2006.11.014

144. Lammers KM, Chieppa M, Liu L, Liu S, Omatsu T, JankaJunttila $M$, et al. Gliadin induces neutrophil migration via engagement of the formyl peptide receptor, FPR1. PLoS ONE. (2015) 10:e0138338. doi: 10.1371/journal.pone. 0138338

145. Beitnes A-CR, Ráki M, Lundin KEA, Jahnsen J, Sollid LM, Jahnsen FL. Density of CD163+CD11c+ dendritic cells increases and CD103+ dendritic cells decreases in the coeliac lesion. Scand J Immunol. (2011) 74:186194. doi: 10.1111/j.1365-3083.2011.02549.x

146. Sollid LM, Molberg O, McAdam S, Lundin KE. Autoantibodies in coeliac disease: tissue transglutaminase-guilt by association? Gut. (1997) 41:8512. doi: $10.1136 /$ gut.41.6.851

147. Comerford R, Coates C, Byrne G, Lynch S, Dunne P, Dunne M, et al. Characterisation of tissue transglutaminase-reactive $\mathrm{T}$ cells from patients with coeliac disease and healthy controls. Clin Immunol. (2014) 154:15563. doi: 10.1016/j.clim.2014.08.001

148. Ciccocioppo R, Finamore A, Mengheri E, Millimaggi D, Esslinger B, Dieterich W, et al. Isolation and characterization of circulating tissue transglutaminase-specific $\mathrm{T}$ cells in coeliac disease. Int J Immunopathol Pharmacol. (2010) 23:179-91. doi: 10.1177/039463201002300116

149. Barnadas MA. Dermatitis herpetiformis: a review of direct immunofluorescence findings. Am J Dermatopathol. (2016) 38:283-8. doi: 10.1097/DAD.0000000000000420

150. Samolitis NJ, Hull CM, Leiferman KM, Zone JJ. Dermatitis herpetiformis and partial IgA deficiency. J Am Acad Dermatol. (2006) 54:S2069. doi: 10.1016/j.jaad.2005.06.033

151. Halttunen T, Mäki M. Serum immunoglobulin a from patients with celiac disease inhibits human T84 intestinal crypt epithelial cell differentiation. Gastroenterology. (1999) 116:566-72. doi: 10.1016/S0016-5085(99)70178-2 
152. Rauhavirta T, Qiao S-W, Jiang Z, Myrsky E, Loponen J, Korponay-Szabó IR, et al. Epithelial transport and deamidation of gliadin peptides: a role for coeliac disease patient immunoglobulin A. Clin Exp Immunol. (2011) 164:127-36. doi: 10.1111/j.1365-2249.2010.04317.x

153. Rauhavirta T, Hietikko M, Salmi T, Lindfors K. Transglutaminase 2 and transglutaminase 2 autoantibodies in celiac disease: a review. Clin Rev Allergy Immunol. (2016) 57:23-38. doi: 10.1007/s12016-016-8557-4

154. Saalman R, Dahlgren UI, Fällström SP, Hanson LÅ, Ahlstedt S, Wold AE. IgG subclass profile of serum antigliadin antibodies and antibody-dependent cell-mediated cytotoxicity in young children with coeliac disease. Scand J Immunol. (2001) 53:92-98. doi: 10.1046/j.1365-3083.2001.00848.x

155. Gallagher RB, Cervi P, Kelly J, Dolan C, Weir DG, Feighery C. The subclass profile and complement activating potential of anti-alpha-gliadin antibodies in coeliac disease. J Clin Lab Immunol. (1989) 28:115-21.

156. Salmi TT, Hervonen K, Laurila K, Collin P, Mäki M, Koskinen O, et al. Small bowel transglutaminase 2-specific IgA deposits in dermatitis herpetiformis. Acta Derm Venereol. (2014) 94:393-7. doi: 10.2340/00015555-1764

157. Roos A, Bouwman LH, van Gijlswijk-Janssen DJ, Faber-Krol MC, Stahl GL, Daha MR. Human IgA activates the complement system via the mannan-binding lectin pathway. J Immunol. (2001) 167:28618. doi: 10.4049/jimmunol.167.5.2861

158. Sziksz E, Veres-Székely A, Pap D, Fekete A, Veres G, Tulassay T, et al. Mucosal Architectural Rearrangement in Coeliac Disease. Int J Celiac Dis. (2016) 2:89-92. doi: 10.12691/ijcd-2-3-5

159. Ciccocioppo R, Di Sabatino A, Bauer M, Della Riccia DN, Bizzini F, Biagi F, et al. Matrix metalloproteinase pattern in celiac duodenal mucosa. Lab Invest. (2005) 85:397-407. doi: 10.1038/labinvest. 3700225

160. Mohamed BM, Feighery C, Kelly J, Coates C, O'Shea U, Barnes L, et al. Increased protein expression of matrix metalloproteinases $-1,-3$, and -9 and TIMP-1 in patients with gluten-sensitive enteropathy. Dig Dis Sci. (2006) 51:1862-8. doi: 10.1007/s10620-005-9038-4

161. Lahdenperä AI, Fälth-Magnusson K, Högberg L, Ludvigsson J, Vaarala O. Expression pattern of T-helper 17 cell signaling pathway and mucosal inflammation in celiac disease. Scand J Gastroenterol. (2014) 49:14556. doi: 10.3109/00365521.2013.863966

162. Simmons JG, Pucilowska JB, Keku TO, Lund PK. IGF-I and TGFbetal have distinct effects on phenotype and proliferation of intestinal fibroblasts. Am J Physiol Gastrointest Liver Physiol. (2002) 283:G80918. doi: 10.1152/ajpgi.00057.2002

163. Bamba S, Andoh A, Yasui H, Araki Y, Bamba T, Fujiyama Y. Matrix metalloproteinase-3 secretion from human colonic subepithelial myofibroblasts: role of interleukin-17. J Gastroenterol. (2003) 38:54854. doi: 10.1007/s00535-002-1101-8

164. O'Keeffe J, Lynch S, Whelan A, Jackson J, Kennedy NP, Weir DG, et al. Flow cytometric measurement of intracellular migration inhibition factor and tumour necrosis factor alpha in the mucosa of patients with coeliac disease. Clin Exp Immunol. (2001) 125:376-82. doi: 10.1046/j.1365-2249.2001. 01594.x

165. Monteleone G, Caruso R, Fina D, Peluso I, Gioia V, Stolfi C, et al. Control of matrix metalloproteinase production in human intestinal fibroblasts by interleukin 21. Gut. (2006) 55:1774-80. doi: 10.1136/gut.2006.093187

166. Roncoroni L, Elli L, Bardella MT, Perrucci G, Ciulla M, Lombardo V, et al. Extracellular matrix proteins and displacement of cultured fibroblasts from duodenal biopsies in celiac patients and controls. J Transl Med. (2013) 11:91. doi: 10.1186/1479-5876-11-91

167. Saada JI, Pinchuk I V, Barrera CA, Adegboyega PA, Suarez G, Mifflin RC, et al. Subepithelial myofibroblasts are novel nonprofessional APCs in the human colonic mucosa. J Immunol. (2006) 177:5968-79. doi: 10.4049/jimmunol.177.9.5968

168. Pinchuk I V., Beswick EJ, Saada JI, Boya G, Schmitt D, Raju GS, et al. Human colonic myofibroblasts promote expansion of CD4+ CD25 high foxp3+ regulatory T cells. Gastroenterology. (2011) 140:201930. doi: $10.1053 /$ j.gastro.2011.02.059

Conflict of Interest: The authors declare that the research was conducted in the absence of any commercial or financial relationships that could be construed as a potential conflict of interest.

Copyright (c) 2020 Dunne, Byrne, Chirdo and Feighery. This is an open-access article distributed under the terms of the Creative Commons Attribution License (CC BY). The use, distribution or reproduction in other forums is permitted, provided the original author(s) and the copyright owner(s) are credited and that the original publication in this journal is cited, in accordance with accepted academic practice. No use, distribution or reproduction is permitted which does not comply with these terms. 